\title{
台湾の母親のダウン症児に対するコミュニケーション・スタイル ——自由遊び場面と食事場面の比較を通して—
}

黄愫芬

\begin{abstract}
本研究では、表出言語水準 (ELA) と平均発話長 (MLU) で一致させたダウン症児 (ELA： 月路 21.0 か月、MLU：1.9） と健常児（ELA：月歯 20.4 か月、MLU：2.2）およびその母 親を 20 組対象とし、各対象者の家庭における自由遊び場面と食事場面について、場面ごとに 母子会話のやりとりと母親の発話の機能について検討していくことを目的とする。その結果、 自由遊び場面におけるダウン症児の母親は健常児の母親より発話数やターン数が多く、食事 場面では差がなかった。母親の発話の機能は場面別にみると、指示は、自由遊び場面で差が あり、食事場面では差がなかった。一方、情報、評価では、食事場面で差があり、自由遊び 場面で差がなかった。このことは、場面によって、母親の話し方が異なっていることを示し ており、1つの場面で集められたデータだけから母親のコミュニケーションスタイルを特定 するのは問題であるということが明らかとなった。
\end{abstract}

キー・ワード：母子相互作用 ダウン症児 母親の発話機能 台湾 MLU

\section{I . 問題と目的}

1970 年代以降、ダウン症児とその母親および健常児 とその母親の相互作用に関する比較研究が英語圏で多 く行われた (Conti-Ramsden, 1989)。これらの研究が 用いた子どものマッチングの変数は、生活年齢、精神 年齢、および言語水準 3 つのいずれかであった。まず、 母親の発話数、ターン数について検討してみる。 Buium, Rynders, and Turnure（1974）は生活年齢を マッチングさせた 24 か月のダウン症児 6 名、健常児 5 名およびその母親を対象とし比較した結果、ダウン症 児の母親は、発話数がより多いと報告している。Davis and Oliver（1980）は、精神年齢をマッチングさせた ダウン症児（月齢 18〜 61 か月）と健常児（月齢 8〜 17 か月）とその母親各 8 組を対象とし比較した結果、ダ ウン症児の母親は発話数がより多いと報告している。

Tannock（1988）は、ダウン症児（月齢 15〜57 か月） の母親は、発達年齢と言語水準をマッチングさせた健 常児 (月齢 10〜22 か月) の母親に比べて、発話数と夕 ーン数が多いと指摘している。以上のようにこれまで の研究結果は、ダウン症児の母親は生活年齢、精神年 齢、発達年齢と言語水準をマッチングさせた健常児の 母親より発話数、ターン数が多いというものであっ

台湾国立台東師範学院幼児教育学系
た。

次に、母親の発話の機能面について検討してみる。 命令、指示について、Matey and Kretschmer (1985) は、生活年齢をマッチングさせたダウン症児 16 名 (月 齢 18 か月 8 名と 3 歳 8 名) と健常児 16 名（月齢 18 か 月 8 名と 3 歳 8 名）およびその母親を比較し、ダウン 症児の母親は命令文が多いと指摘している。Cardoso and Mervis（1985）は、精神年㱓をマッチングさせた ダウン症児（月齢 $21.5 \sim 37.1$ か月）と健常児（月齢 $12.1 \sim 15.2$ か月）およびその母親各 5 組を比較し、ダ ウン症児の母親のほうが命令文が多いという結果を示 している。また、陳（1991）はダウン症児と生活年齢 または精神年齢をマッチングさせた健常児各 11 組の 3 群の母子相互作用を比較している。その結果、ダウ ン症览の母親は精神年龄または生活年齢をマッチング させた健常児の母親と比べて、より多くの命令文を使 用していた。一方、Rondal（1977）は、平均発話長 (MLU) をマッチングさせたダウン症児 (月齢 $36 〜 144$ か月）と健常児（月齢 20〜32 か月）およびその母親各 21 組を比較し、ダウン症児と健常児の母親の指示文に 差はないと報告している。

先の Matey and Kretschmer（1985）は、ダウン症 児の母親は生活年齢をマッチングさせた健常児の母親 に比べて、質問が少ないとしている。また、Leifer and 
Lewis（1983）は、生活年齢をマッチングさせたダウン 症児 (月齢 18〜23 か月 4 名) と健常児 (月榆 18〜23 か 月 4 名)およびその母親、また、MLUをマッチングさ せたダウン症児（4 歳 6 名）と健常児（月齢 18〜23 か 月 4 名）およびその母親を対象とし、母親の子どもへ の質問文のタイプについて比較した。その結果、生活 年齢をマッチングさせた群では、ダウン症児の母親の ほうがテスト質問、明確化要請㧍よび確認要請の割合 が低く、指示の割合が高かった。総質問数は差がなか つた。これに対し、MLUをマッチングさせた群間に 差はなかった。

先の Davis and Oliver（1980）は、ダウン症児の母 親は、精神年齢をマッチングさせた健常児の母親に比 べて、子どもの発声に対して応答的であると報告して いる。また、Fischer（1987）峿言語水準と発達年齢を マッチングさせたダウン症児（月齢 19〜28 か月）と健 常児（月齢 10.6〜17.3 か月）とその母親各 5 組を対象 として比較した結果、ダウン症児の母親の応答性が高 いと報告している。Petersen and Sherrod (1982) は、 MLU をマッチングさせたダウン症児 (月齢 25〜38 か 月)、言語遅滞児 (月齢 $24 \sim 48$ か月)、健常児 (月齢 18〜30 か月）各 10 名抢よびその母親を比較し、母親 の応答に差がないと報告している。

以上のことにより、命令、指示、質問、応答の機能 について、生活年秢や精神年齢をマッチングさせたグ ループではダウン症児と健常児の母親の言語に差が表 れやすく、言語水準や MLU でマッチングさせるとそ れがみられないということが示されている。つまり、 英語圏では、ダウン症児の母親と健常児の母親を比べ ると、子どもの言語水準により母親の発話機能が変わ り、子どもの障害の有無は関係しないと考えられる。 したがって、ダウン症児と健常児の母子相互作用を比 較しようとする研究では、ダウン症児と健常児が同じ 言語水準であるか否かを配慮すること、言語水準を詳 細に測定することが必要であると考えられる。生活年 齢、精神年齢を健常児とマッチングさせたダウン症児 の話し言葉は、同じ生活年齢や精神年齢の健常児の話 し言葉と比較して、言語発達の面で明らかな遅滞を示 している (Marshall, Hegrenes, \& Goldstein, 1973)。 一方、Rondal (1977) は、MLUによってマッチング させると、ダウン症児の話し言葉が同じ MLU の健常 児の言葉と、よく似ていると報告している。したがっ て、本研究では、子どもの言語水準をより厳密にマッ チングさせるために、言語水準と MLU でマッチング させた。
また、これまでの母子相互作用の研究には別の問題 もある。すなわち、母子相互作用の中での言語パター ンについてのみ検討しており、母子相互作用に影響を 与えると考えられる文脈については検討されていな い。母子相互作用が文脈による影響をかなり受けてお り、単一の場面から結果を導くことの危険性が示唆さ れている (Hoff-Ginsberg, 1991)。

さて、英語圏で頻繁に観察される場面のほとんどは 自由遊び場面であるが、絵本のよみきかせ（Snow, Perlman, \& Nathan, 1987) あるいはテーブルセッテ イング（Buium ら，1974）のような他の場面と自由遊 び場面との間で母親の発話機能が異なることが指摘さ れている。観察は、実験室または家庭、臨床場面で行 われることが多い。Gunn, Clark, and Berry (1980) によると、もし母親と子どもが実験室に慣れていなけ れば、彼らは自然な行動をとれず、厳密なデー夕を取 ることができない。以上を考えると母子相互作用の研 究は母子が慣れている複数場面で行うことが望まし い。

本研究では、子どもの言語水準を厳密にマッチング させるために言語年齢と MLU の両方でマッチングさ せたダウン症児と健常児およびその母親を対象とし、 子どもと母親が慣れている各被験者の家庭における自 由遊び場面と日常生活に密着した食事場面という $2 つ$ の場面でのやりとりを設定した。自由遊び場面は、英 語圈で頻繁に観察される場面のほとんどが自由遊び場 面なので、それと比較するために設定した。また、食 事場面は、母親が子どもに食事中のマナーを教えるな ど母親側の要請が強い場面であると考えられるので、 設定した。そこで、2 場面で自由遊び場面と食事場面 について、場面ごとに母子会話のやりとりと母親の発 話の機能について検討していくことを目的とする。

\section{II. 方 法}

\section{1. 被験者}

本研究には、表出言語年齢（ELA: expressive language age) と MLUでマッチングさせたダウン症児 および健常児各 20 名、ならびに彼らの母親が参加し た。全員に学齢前児童行為発展量表 (Chinese Child Development Inventory) を実施し、ELA を算出し た。ELAにしたのは、この検查で算出される言語年齢 が表出に限定されているからである。次に MLU は台 湾で取られている2つの計算方法、「音節指標（syllable)」「語詞指標（word）」のうち、後者を使用した。 「音節指標」（張, 1998）を用いて、2 場面の発話数の合 
台湾の母親のダウン症児に対するコミュニケーション・スタイル

Table 1 対象児のプロフィール

\begin{tabular}{|c|c|c|c|c|c|c|c|}
\hline ダウン症児 & $\mathrm{CA}$ & ELA & MLU & 健常児 & $\mathrm{CA}$ & ELA & MLU \\
\hline 1 & 35 & 17 & 1.4 & 1 & 19 & 18 & - \\
\hline 2 & 39 & 18 & 1.5 & 2 & 28 & 29 & 3.2 \\
\hline 3 & 63 & 36 & 2.6 & 3 & 26 & 25 & 2.9 \\
\hline 4 & 66 & 22 & 1.7 & 4 & 12 & 12 & - \\
\hline 5 & 54 & 28 & 2.8 & 5 & 20 & 19 & 2.8 \\
\hline 6 & 68 & 20 & - & 6 & 24 & 25 & 2.6 \\
\hline 7 & 72 & 18 & 1.3 & 7 & 24 & 25 & 2.1 \\
\hline 8 & 59 & 24 & 1.9 & 8 & 24 & 26 & 2.6 \\
\hline 9 & 43 & 28 & 1.8 & 9 & 19 & 17 & 2.0 \\
\hline 10 & 70 & 32 & 2.9 & 10 & 18 & 16 & 1.8 \\
\hline 11 & 47 & 21 & 1.3 & 11 & 12 & 12 & - \\
\hline 12 & 61 & 17 & 1.6 & 12 & 20 & 18 & 1.2 \\
\hline 13 & 38 & 15 & 1.8 & 13 & 19 & 18 & 1.8 \\
\hline 14 & 62 & 16 & - & 14 & 23 & 22 & 1.7 \\
\hline 15 & 47 & 22 & 2.2 & 15 & 23 & 22 & 1.2 \\
\hline 16 & 70 & 24 & 2.0 & 16 & 27 & 25 & 3.1 \\
\hline 17 & 48 & 14 & - & 17 & 15 & 13 & 1.5 \\
\hline 18 & 38 & 13 & 1.2 & 18 & 25 & 25 & 2.4 \\
\hline 19 & 74 & 20 & 1.9 & 19 & 25 & 26 & 2.7 \\
\hline 20 & 62 & 14 & - & 20 & 17 & 14 & 1.8 \\
\hline 平均 & 55.8 & 21.0 & 1.9 & 平均 & 21.0 & 20.4 & 2.2 \\
\hline 標準偏差 & 12.5 & 6.1 & 0.5 & 標準偏差 & 4.6 & 5.2 & 0.6 \\
\hline
\end{tabular}

一は，発話数が 15 に満たないことを示す.

計より算出した。ただし、発話数が 15 に満たない 7 名 （ダウン症児 4、健常児 3 名）はMLUを計算しなかっ た。ダウン症児は、台北市のダウン症児センター (Down Syndrome Association of R.O.C) において言 語指導を受けている就学前の男児 13 名、女览 7 名で全 員 21 トリソミーと診断されている。月齢は 35〜 74 か 月 $(\mathrm{M}=55.8, \mathrm{SD}=12.5) 、 \mathrm{ELA}$ は $13 \sim 36$ か月 $(\mathrm{M}=$ 21.0, $\mathrm{SD}=6.1) 、 \mathrm{MLU}$ は $1.2 \sim 2.9(\mathrm{M}=1.9, \mathrm{SD}=$

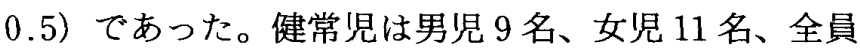
台北市在住で、一般の幼稚園に通園またはべビーシッ ターに預けられている。月齢は 12〜 28 か月（ $\mathrm{M}=$ $21.0, \mathrm{SD}=4.6) 、 \mathrm{ELA}$ は $12 \sim 29$ か月 $(\mathrm{M}=20.4$, $\mathrm{SD}=5.2) 、 \mathrm{MLU}$ は $1.2 \sim 3.2(\mathrm{M}=2.2, \mathrm{SD}=0.6)$ で あった。両群のELA月齢 $(\mathrm{U}=198 ; \mathrm{p}>.10)$ と MLU（U=97; p>.10）には差がない。対象児のプロ フィールを Table 1 に示した。

\section{2. 用 具}

用具は、ままごとセット（包丁、5つの果物、まな 板）と防み（ミッキーマウス）と車 2 台、ブロ ック、積木、絵本 2 冊、人形 4 つ、音の出る玩具を使
用した。食事は母親に普段通りに用意してもらった。

\section{3. 手続き}

各家庭を 1 人の観察者が訪問し、原則として自由遊 び、次いで食事の順序で母子に自由にやりとりを行っ てもらい、また、母親にはできるだけ普段と同様に接 してもらうように教示した。それぞれの場面を約 30 分ずつビデオに録画した。ただし、その日の子どもの 状態によって、自由遊びの前に食事を行ったケースが 5 組あった。自由遊びを始めてから 30 分以上たっての ち観察者がおもちゃを片づけるように促し、食事は子 どもがやめるまで録画したが、10 分経過する前に子ど もがやめようとした場合には観察者がアイコンタクト や身振りで続けるように母親を促した。他の家族がい る場合には、自由遊び場面や食事場面の中に参加せず、 別の部屋にいてもらった。

\section{4. 資料収集・分析}

自由遊び場面 30 分の中間 10 分間（最初の 10 分間 はウォーミングアップ）と、食事場面は食べ始めてか ら 10 分間（子どもの食事時間には個人差があり、早 い子どもに合わせた)、計 20 分間のビデオ記録から母 
Table 2 母親の発話の機能的カテゴリーと定義

\begin{tabular}{|c|c|}
\hline カテゴリー & 定義 \\
\hline 指示 & $\begin{array}{c}\text { 指示, 命令, 注意, 要請など, 相手に特定の行動を求める } \\
\text { 例：これを見なさい. 玩具を取って. 早く食べなさい. }\end{array}$ \\
\hline 質問 & 相手に返事や説明を求める問いかけ \\
\hline WH 型質問 & $\begin{array}{l}\text { WH 型質問を使って, 相手に返事や説明を求める問いかけ } \\
\text { 例：これは何？どこに行くの? }\end{array}$ \\
\hline Yes/No 型質問 & $\begin{array}{l}\text { Yes/No 型質問を使って, 相手に返事や説明を求める問いかけ } \\
\text { 例：これいる？リンゴ好き? }\end{array}$ \\
\hline 情報 & $\begin{array}{l}\text { 相手に知識や情報を与える } \\
\text { 例：リンゴの色は赤ね. この野菜は人参よ. }\end{array}$ \\
\hline 評価 & 相手の行動, 成果に対する評価反応 \\
\hline 正評価 & $\begin{array}{l}\text { 相手の行動, 成果に対する正評価反応 } \\
\text { 例：上手ね.よくできたね. }\end{array}$ \\
\hline 負評価 & $\begin{array}{l}\text { 相手の行動, 成果に対する負評価反応 } \\
\text { 例：下手ね. ちょっと違うね. }\end{array}$ \\
\hline 応答 & $\begin{array}{l}\text { 問い, 話しかけなどに対する反応 } \\
\quad \text { 例：子ども「ご飯をたべたい」母親「どうぞ」 }\end{array}$ \\
\hline その他 & $\begin{array}{l}\text { 上記に当てはまらないもの } \\
\text { 例：歌う, 不明瞭な発話など. }\end{array}$ \\
\hline
\end{tabular}

子会話を文字転写し、その資料をもとに、それぞれの 会話を Tannock (1988) と McDonald and Pien （1982）が用いた方法を参考にして分析した。

1) 母子会話のやりとり

(1) 発話数：発話は次のように定義した。1つの 文が 1 つの発話（例：「遊びたい?」)。複数の文でも 接続詞を使って 1 つの文になっている場合は 1 つの発 話 (例：「ご飯を食べるからおもちゃ片付けて」)。ま

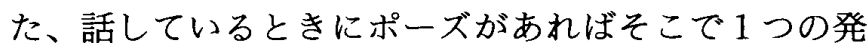

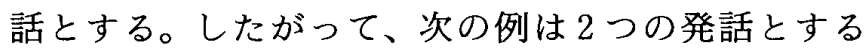
(例：「あっ、」ポーズ「これを使って」)。

(2) ターン数：ターンは次のように定義した。親 または子どもが話し始めて終わるまでのひとまとまり の内容をもつもので、次の例では母子それぞれ 1 ター ンとなる。(例：母親「遊びたい?」子ども「うん」)。 1 つのターンは、1 発話のこともあれば複数の発話か ら成ることもある。次の母親の例では 2 つの発話を 1 つのターンとする。(例：母親「電車、遊びたい?\} 子ども「うん」)。なお、1つのターンには、話し始め て終わるまでに、1秒以上の何もなされない休止を含 まないものとした。

(3) ターンの長さ：発話数/ターン数

(4) MLU：場面ごとに 100 発話で算出した。ただ
し、ダウン症児の母親 1 名は食事場面において 100 発 話に満たなかったため、全 81 発話を用いた。

(5) 母親の主導権 (発話数およびターン数の母子間 のバランス)：母の発話数/子どもの発話数、母の夕 ーン数/子どものターン数を算出した。

2）母親の発話機能：母親の全発話を Table 2 に示す機能的カテゴリーに沿って分類した。

\section{5. 信頼性}

文字転写、発話とターンの特定、母親の発話機能の 分類は、筆者と台湾からの大学院の文化人類学専攻の 留学生 1 名との協議で一致した結果に基づいて行われ た。評定の信頼性をみるために、別の台湾からの大学 院の国文学専攻の留学生 1 名が単独で全員 40 人分の 母親の全発話について、母親の発話機能を分類した。 一致数を一致数十不一致数の和で除して 100 倍した一 致率を計算した。2つの評定間の一致率は、87〜95\% であった。

\section{III. 結 果}

1. 母子会話のやりとり

会話のやりとり（Table 3）と母親の発話の機能 (Table 4) について、2つの群に差があるか否かを Mann Whitney U test で検定した。 
Table 3 母子の会話のやりとり

\begin{tabular}{|c|c|c|c|c|c|c|}
\hline \multirow[b]{2}{*}{ 母親 } & \multicolumn{2}{|c|}{ 自由遊び場面 } & \multicolumn{2}{|c|}{ 食事場面 } & \multicolumn{2}{|c|}{ 自由遊び場面＋食事場面 } \\
\hline & $\begin{array}{l}\text { ダウン症児 } \\
\text { M (SD) }\end{array}$ & $\begin{array}{l}\text { 健常児 } \\
\mathrm{M} \text { (SD) }\end{array}$ & $\begin{array}{l}\text { ダウン症児 } \\
\text { M (SD) }\end{array}$ & $\begin{array}{l}\text { 健常児 } \\
\text { M (SD) }\end{array}$ & $\begin{array}{l}\text { ダウン症児 } \\
\text { M (SD) }\end{array}$ & $\begin{array}{l}\text { 健常児 } \\
\text { M (SD) }\end{array}$ \\
\hline 発話数 $/ 10$ 分 & $330.2(107.0)$ & $260.2(45.6) * *$ & $232.5(71.0)$ & $256.0(86.2)$ & $562.7(134.3)$ & $516.2(124.5)$ \\
\hline ターン数 $/ 10$ 分 & $138.5(37.8)$ & $114.1(32.1)^{*}$ & $102.8(38.8)$ & $109.8(28.6)$ & $241.3(72.0)$ & $223.8 \quad(53.7)$ \\
\hline $\begin{array}{c}\text { ターンの長さ (発話数／ } \\
\text { ターン数) }\end{array}$ & $2.4 \quad(0.7)$ & $2.4(0.8)$ & $2.4(0.9)$ & $2.3(0.6)$ & $2.4(0.7)$ & $2.3(0.6)$ \\
\hline MLU & $3.6(0.6)$ & $3.6(0.6)$ & $3.6(0.5)$ & $3.4(0.7)$ & $3.6(0.5)$ & $3.5(0.5)$ \\
\hline 母親の主導権 & & & & & & \\
\hline $\begin{array}{l}\text { 発話数のバランス（母 } \\
\text { 親の発話数／子ども } \\
\text { の発話数 })\end{array}$ & $6.4(4.0)$ & $8.2(7.5)$ & $14.3(18.3)$ & $6.6(3.4)$ & $7.6(5.8)$ & $6.6(4.6)$ \\
\hline $\begin{array}{l}\text { ターン数のバランス } \\
\text { (母親のターン数／ } \\
\text { 子どものターン数) }\end{array}$ & $3.1 \quad(2.2)$ & $3.8(3.0)$ & $5.5(6.6)$ & $3.2(1.4)$ & $3.4 \quad(2.1)$ & $3.1(1.6)$ \\
\hline 子ども & & & & & & \\
\hline 発話数 $/ 10$ 分 & $68.4(33.4)$ & $62.1(41.0)$ & $41.5 \quad(34.2)$ & $46.4 \quad(19.8)$ & $109.9(61.8)$ & $108.4(54.9)$ \\
\hline ターン数 $/ 10$ 分 & $58.9(27.7)$ & $49.7 \quad(29.6)$ & $37.5(29.6)$ & $39.9(16.2)$ & $96.4 \quad(53.6)$ & $89.6(41.2)$ \\
\hline $\begin{array}{l}\text { ターンの長さ (発話数 } / \\
\text { ターン数) }\end{array}$ & $1.2(0.1)$ & $1.2(0.2)$ & $1.1(0.1)$ & $1.2(0.1)^{*}$ & $1.1(0.1)$ & $1.2(0.1)$ \\
\hline
\end{tabular}

Table 4 母親の発話の各機能の割合

\begin{tabular}{|c|c|c|c|c|c|c|}
\hline \multirow[b]{2}{*}{ 発話機能 } & \multicolumn{2}{|c|}{ 自由遊び場面 } & \multicolumn{2}{|c|}{ 食事場面 } & \multicolumn{2}{|c|}{ 自由遊び場面＋食事場面 } \\
\hline & $\begin{array}{c}\text { ダウン症児 } \\
\text { M (SD) }\end{array}$ & $\begin{array}{c}\text { 健常児 } \\
\text { M（SD） }\end{array}$ & $\begin{array}{c}\text { ダウン症児 } \\
\text { M (SD) }\end{array}$ & $\begin{array}{c}\text { 健常児 } \\
\text { M (SD) }\end{array}$ & $\begin{array}{c}\text { ダウン症児 } \\
\text { M (SD) }\end{array}$ & $\begin{array}{c}\text { 健常児 } \\
\text { M（SD） }\end{array}$ \\
\hline 指示 & $98.1(25.8)$ & $75.7(30.4)^{*}$ & $95.2(46.8)$ & $99.4 \quad(36.7)$ & $193.3(48.9)$ & $175.1(58.1)$ \\
\hline 質問 & $63.6(22.5)$ & $45.3(14.5)^{*}$ & $40.6(14.6)$ & $33.0(18.0)^{*}$ & $104.2(29.3)$ & $78.3(28.5)^{* *}$ \\
\hline WH 型質問 & $40.9(14.7)$ & $21.5(5.9)^{* *}$ & $21.8(11.9)$ & $12.0(7.9)$ & $62.7(17.4)$ & $33.5(7.7)^{* *}$ \\
\hline Yes/No 型質問 & $22.8(10.9)$ & $23.8(14.0)^{* *}$ & $18.8(12.9)$ & $21.0(14.9)$ & $41.6 \quad(19.7)$ & $44.8(23.3)^{* *}$ \\
\hline 情報 & $109.1(42.0)$ & $74.1 \quad(24.2)$ & $66.8(14.6)$ & $65.0(30.6)^{*}$ & $175.9(50.0)$ & $139.1(39.0)$ \\
\hline 評価 & $8.0(8.6)$ & $4.5(3.2)$ & $10.8(7.1)$ & $6.3(3.8)^{*}$ & $18.8(12.5)$ & $10.8(5.7)^{*}$ \\
\hline 正評価 & $5.9(8.4)$ & $3.0(2.6)$ & $9.6(7.0)$ & $4.7(3.3)$ & $15.4(12.3)$ & $7.6(4.8)^{*}$ \\
\hline 負評価 & $2.2(1.7)$ & $1.6(1.1)$ & $1.2(1.0)$ & $1.7(1.5)$ & $3.4(1.9)$ & $3.2(1.9)^{*}$ \\
\hline 応答 & $13.0(5.8)$ & $15.3(3.5)^{* *}$ & $6.3(7.1)$ & $15.0(10.4)^{* *}$ & $19.3(10.5)$ & $30.3(11.7)^{*}$ \\
\hline その他 & $38.5 \quad(19.3)$ & $45.4(20.6)^{* *}$ & $12.9(5.8)$ & $37.4(21.2)^{* *}$ & $51.3(20.6)$ & $82.7(39.4)^{* *}$ \\
\hline
\end{tabular}

1）発話数：自由遊び場面において、ダウン症児 の母親は健常児の母親と比べて発話数が多く $(U=$ 298; $\mathrm{p}<.01 ） 、$ 食事場面、自由遊びと食事を合わせた 全場面では、ともに差が認められなかった（U=173; $\mathrm{p}>.10, \mathrm{U}=245 ; \mathrm{p}>.10)$ 。ダウン症児と健常児とで は、自由遊び場面、食事場面および自由遊びと食事を
合わせた全場面のいずれでも、発話数に差はなかった $(\mathrm{U}=222.5 ; \mathrm{p}>.10, \mathrm{U}=155 ; \mathrm{p}>.10, \mathrm{U}=200.5$; $\mathrm{p}>.10)$ 。

2 ）ターン数：自由遊び場面では、ダウン症児の 母親は健常児の母親と比べてターン数が多く $(U=$ $274 ; \mathrm{p}<.05 ） 、$ 食事場面、自由遊びと食事を合わせた 
全場面では、ともに差が認められなかった（U=179.5; $\mathrm{p}>.10, U=221 ; \mathrm{p}>.10)$ 。ダウン症児と健常児とで は、自由遊び場面、食事場面および自由遊びと食事を 合わせた全場面のいずれでも、ターン数の差はなかっ た。 $(\mathrm{U}=232 ; \mathrm{p}>.10, \mathrm{U}=159 ; \mathrm{p}>.10, \mathrm{U}=207.5$; $\mathrm{p}>.10)$

3 ）ターンの長さ：ダウン症児の母親と健常児 の母親とでは、自由遊び場面、食事場面、自由遊びと 食事を合わせた全場面のいずれでも、ターンの長さに 差はなかった $(\mathrm{U}=202.5 ; \mathrm{p}>.10, \mathrm{U}=217 ; \mathrm{p}>.10$, $\mathrm{U}=227.5 ; \mathrm{p}>.10)$ 。ダウン症児は健常児と比べて、食 事場面でターンの長さには差があったが（U=109; $\mathrm{p}<.05$ )、自由遊び場面、自由遊びと食事を合わせた全 場面では、ともに差が認められなかった（U=160.5; $\mathrm{p}>.10, \mathrm{U}=139 ; \mathrm{p}>.10)$ 。

4) MLU：母親の MLUは、自由遊び場面、食事 場面、自由遊びと食事を合わせた全場面のいずれでも 2 つの群に差はみられなかった（U=188.5; p>.10， $\mathrm{U}=253.5 ; \mathrm{p}>.10, \mathrm{U}=208.5 ; \mathrm{p}>.10) 。$

5 ）母親の主導権（発話数の母子間のバランス）: 発話数の母子間のバランスは、自由遊び場面、食事場 面、自由遊びと食事を合わせた全場面のいずれでも、 2 つの群に差はなかった $(\mathrm{U}=216.5 ; \mathrm{p}>.10, \mathrm{U}=236$; $\mathrm{p}>.10, \mathrm{U}=217 ; \mathrm{p}>.10)$ 。

6 ）母親の主導権（ターン数の母子間のバラン ス）：ターン数の母子間のバランスは、自由遊び場面、 食事場面、自由遊びと食事を合わせた全場面のいずれ でも 2 つの群に差はなかった $(\mathrm{U}=203 ; \mathrm{p}>.10, \mathrm{U}=$ $227.5 ; \mathrm{p}>.10, \mathrm{U}=200.5 ; \mathrm{p}>.10) 。$

\section{2. 母親の発話の機能}

母親の総発話数に対するそれぞれの機能分類の占め る割合に基づいて両群を比較した。

1）機能分類の割合：自由遊び場面では、ダウン 症児の母親は健常児の母親と比べて、指示 $(U=278.5$; $\mathrm{p}<.05)$ 、質問 $(\mathrm{U}=283.5 ; \mathrm{p}<.05)$ の割合が高く、応 答（U=84； $\mathrm{p}<.01 ）$ が低かった。食事場面では、 ダウン症児の母親は健常児の母親と比べて、質問 $(\mathrm{U}=289.5 ; \mathrm{p}<.05)$ 、情報（ $\mathrm{U}=276.5 ; \mathrm{p}<.05 ） 、$ 評 価（U=286; $<<.05 ）$ の割合が高く、応答 $(U=95$; $\mathrm{p}<.01 ） か ゙$ 低かった。自由遊びと食事を合わせた全場 面では、ダウン症児の母親は健常児の母親と比べて、 質問 $(U=296 ; p<.01) 、$ 評価 $(U=277 ; p<.05)$ の割 合が高く、応答 $(U=69 ; p<.01)$ が低かった。

2) WH 型質問と Yes, No 型質問の機能：母親 の総質問発話数に対してWH 型と Yes/No 型それぞ
れの質問の機能分類の占める割合に基づいて両群を比 較した。自由遊び場面でダウン症児の母親は健常児の 母親と比べて、WH 型質問 $(\mathrm{U}=301.5 ; \mathrm{p}<.01)$ の割 合が高く、Yes/No 型質問 $(U=98.5 ; \mathrm{p}<.01)$ が低か った。食事場面では、ダウン症児の母親と健常児の母 親で、WH 型質問 $(U=269.5 ; \mathrm{p}>.10) 、 Y e s / N o$ 型 質問（U=130.5； p>.10）に差がみられなかった。自 由遊びと食事を合わせた全場面でダウン症児の母親 は健常児の母親と比べて、WH型質問 $(\mathrm{U}=331$; $\mathrm{p}<.01 ）$ の割合が高く、Yes/No 型質問 $(U=69$; $\mathrm{p}<.01 ）$ が低かった。

3) 正、負評価の機能：母親の総評価発話数に対 して正、負それぞれの評価の機能分類の占める割合に 基づいて両群を比較した。自由遊び場面では、ダウン 症児の母親と健常児の母親で、正評価 $(U=187$; $\mathrm{p}>.10)$ 、負評価 $(U=213 ; \mathrm{p}>.10)$ に差がみられな かった。食事場面でも、ダウン症児の母親と健常児の 母親とで、正評価 $(U=271 ; p>.10)$ 、負評価 $(U=129$; $\mathrm{p}>$ ．10）には差がみられなかった。自由遊びと食事を 合わせた全場面では、ダウン症児の母親は健常児の母 親と比べて、正評価 $(\mathrm{U}=280 ; \mathrm{p}<.05)$ の割合が高く、 負評価（U=120； $<<.05 ）$ が低かった。

\section{IV. 考 察}

自由遊び場面におけるダウン症児の母親と健常児の 母親のMLUには差がないという本研究結果は、 MLU で両群をマッチングした Petersen and Sherrod (1982)、Rondal (1977) の研究と一致する。また、自 由遊び場面において、ダウン症児の母親は健常児の母 親より発話数、ターン数が多いという本研究の結果は、 同様に言語水準で両群をマッチングした Tannock （1988）の研究と一致する。しかし、本研究でとりあげ た食事場面での発話数、ターン数については、自由遊 び場面と違って、両群に差がないことが示された。ま た、自由遊び場面と食事場面を合わせると、両群の発 話数、ターン数に差がみられなかった。ダウン症をも つか否かが母親の会話スタイルに与える影響が場面に よって異なることが本研究では示唆された。これは、 Buckhalt, Rutherford, and Goldberg (1978)、Buium ら（1974）などの指摘に沿うものである。したがって、 母子相互作用の研究について、複数以上の場面で観察 するなど、より幅広い言語環境からのデータに基づく 評価が必要と考えられる。また、ここで得られた場面 による違いの意味を今後検討することも求められる。

自由遊び場面で、ダウン症児の母親は健常児の母親 
に比べて指示の機能の割合が高いという本研究の結果 は、生活年齢または精神年歯をマッチングさせた健常 児と比較した Buium ら (1974)、Cardoso and Mervis (1985)、Cunningham, Reuler, Blackwell, and Deck （1981）、陳（1991）の研究と一致をみた。一方、本研 究と同じ自由遊び場面における MLUをマッチングさ せた健常児と比較すると、Rondal（1977）が「母親の 指示は差がなかった」と示した結果と一致しなかっ た。また、ダウン症児の母親は健常児の母親に比べて 質問の機能の割合が高いという本研究の結果に対し て、Leifer and Lewis（1983）は自由遊び場面におい てMLUをマッチングさせた健常児と比較すると、 「母親の質問は差がなかった」としている。また、生 活年齢をマッチングさせた健常児と比較した Matey and Kretschmer（1985）はダウン症児の母親のほうが 質問の機能が少ないとしている。次に、ダウン症児の 母親は健常児の母親に比べて応答の機能の割合が低い という本研究の結果は、精神年齢をマッチングさせた 健常児と比較し、ダウン症児の母親の応答性が低いと した研究 (Eheart, 1982) と一致する。一方、Petersen and Sherrod (1982) の、自由遊び場面におりる MLU をマッチングさせた健常児と比較すると、「母親の応 答は差がなかった」という結果と一致しなかった。

結果は上述のように、MLUでマッチングさせた先 行研究とはいずれも一致せず、精神年龄でマッチング させた先行研究とはいずれも一致した。したがって、 英語圏では、子どもの言語が同じ水準なら、ダウン症 であるかないかにかかわらず、母親の発話機能は変わ らないと考えられる。一方、台湾ではダウン症児の母 親と健常児の母親を比べると、子どもの言語水準が同 じでも母親の発話機能が変わる。それがなぜなのかを 検討する必要がある。ダウン症児の母親の発話機能に 関する英語圈と台湾のこのような違いには、言語と文 化の違いが影響した可能性があると考えられる。この 点は、今後の検討課題である。

また、母親の発話の機能についても場面による違い があり、ダウン症児の母親と健常児の母親とで、指示 の機能は自由遊び場面で差があり、食事場面で差がな く、情報、評価の機能は、食事場面で差があり、自由 遊び場面で差がなかった。会話のやりとりと同じく子 どものダウン症の有無が母親の発話の機能に与える影 響にも場面による違いがあると考えられる。母親の発 話機能についての場面の違いの意味について、今後の 検討が必要である。なお、自由遊び場面や食事場面と それぞれでは差がない場合も、それらを合わせると、
指示、情報以外の発話の機能は全部差がみられた。2 つ場面を合わせたためにデータが増え、差が出やすく なったと考えられる。この点は、今後の検討の課題で ある。

\section{謝 辞}

本論文を作成するにあたり、調查にご協力頂きまし た台湾のダウン症協会およびダウン症児と健常児、そ の母親の皆様に心より感謝申し上げます。そして、貴 重なご助言、ご指導を賜りました金沢大学教授大井学 先生に心より感謝の辞を述べさせていただきたいと思 います。

\section{文 献}

Buckhalt, J. A., Rutherford, R. B., \& Goldberg, K. E. (1978) Verbal and nonverbal interaction of mothers with their Down's syndrome and nonretarded infants. American Journal of Mental Deficiency, 82, 337-343.

Buium, N., Rynders, J., \& Turnure, J. (1974) Early maternal linguistic environment of normal and Down's syndrome language-learning children. American Journal of Mental Deficiency, 79, 52-58.

Cardoso, M. C. \& Mervis, C. B. (1985) Maternal speech to prelinguistic children with Down's syndrome. American Journal of Mental Deficiency, 89, 451-458. 張 顕達 (1998) 平均語句長度在中文的應用. 聽語會 刊, 36-47.

陳 美琇（1991）智能不足與正常児童組母子互動中母 親口語及児童反應行為之研究. 国立台湾師範大學特 殊教育研究所碩士學位論文.

Conti-Ramsden, G. (1989) Parent-child interaction in mental handicap: An evaluation. In M. Beveridge, G. Conti-Ramsden, \& I. Leudar (Eds.), Language and communication in mentally handicapped people. Chapman and Hall, London.

Cunningham, C. E., Reuler, E., Blackwell, J., \& Deck, J. (1981) Behavioral and linguistic developments in the interactions of normal and retarded children with their mothers. Child Development, 52, 62-70.

Davis, H. \& Oliver, B. (1980) A comparison of aspects of the maternal speech environment of retarded and non-retarded children. Child Care Health and Development, 6, 135-145.

Eheart, B. K. (1982) Mother-child interactions with 
nonretarded and mentally retarded preschoolers. American Journal of Mental Deficiency, 87, 20-25.

Fischer, M. A. (1987) Mother-child interaction in preverbal children with Down syndrome. Journal of Speech and Hearing Disorders, 52, 179-190.

Gunn, P., Clark, D., \& Berry, P. (1980) Maternal speech during play with a Down's syndrome infant. Mental Retardation, 18(1), 15-18.

Hoff-Ginsberg, E. (1991) Mother-child conversation in different social classes and communicative settings. Child Development, 62, 782-796.

Leifer, J. \& Lewis, M. (1983) Maternal speech to normal and handicapped children: A look at question-asking behavior. Infant Behavior and Development, 6, 175-187.

Marshall, N., Hegrenes, J., \& Goldstein, S. (1973) Verbal interactions: Mothers and their retarded children versus mothers and their nonretarded children. American Journal of Mental Deficiency, 77, 415-419.

Matey, C. \& Kretschmer, R. (1985) A comparison of mother speech to Down's syndrome, hearingimpaired, and normal-hearing children. Volta Review, 87, 205-213.
McDonald, L. \& Pien, D. (1982) Mother conversational behavior as a function of interactional intent. Journal of Child Language, 9, 337-358.

Petersen, G. A. \& Sherrod, K. B. (1982) Relationship of maternal language to development and language delay of children. American Journal of Mental Deficiency, 86, 391-398.

Rondal, J. (1977) Maternal speech in normal and Down's syndrome children. In P. Mittler (Ed.), Research into practice in mental retardation: Vol. 2. Education and training. University Park Press, Baltimore, MD, 239-244.

Snow, C. E., Perlmann, R., \& Nathan, D. (1987) Why routines are different: Toward a multiple-factors model of the relation between input and language acquisition. In K. Nelson \& A. van Kleeck (Eds.), Children's language, Vol. 6. Laurence Erlbaum, Hillsdale, NY, 65-97.

Tannock, R. (1988) Mother's directiveness in their interactions with their children with and without Down syndrome. American Journal on Mental Retardation, 93, 154-165.

-2000.11 .22 受稿, 2002.4.27 受理一 


\title{
Maternal Communication Style to Taiwanese Children With and Without Down Syndrome: Free Play Versus Meal Time
}

\author{
Sufen HuANG \\ National Taitung Teachers College \\ (Taitung, Taiwan, 950)
}

The purpose of the present study was to investigate turn-taking behavior and the function of utterances produced by mothers when communicating with their children with Down syndrome, by comparing such mothers to the mothers of children without Down syndrome. Forty children (20 with Down syndrome and 20 without) and their mothers participated. The 2 groups of children were matched for Expressive Language Age (ELA) and MLU. Each mother-child dyad was videotaped at home during free play and at meal time. It was found that during free play, the mothers of children with Down syndrome produced more utterances and turns than the mothers of children with no disabilities, but this difference was not observed during mealtime. During free play, the mothers of children with Down syndrome produced more directions and questions, and fewer responses than the other mothers. At mealtime, the mothers of children with Down syndrome produced more questions, information, and evaluations, and fewer responses than the other mothers. When the 2 conditions were combined, the mothers of children with Down syndrome were found to have produced more questions and evaluations, and fewer responses than the other mothers. The results indicate that it would be undesirable to characterize maternal communication style using data collected in only one situation.

Key Words: mother-child interaction, language, Taiwan, MLU, children with Down syndrome 